\title{
Animal Minds, Social Change, and the Future of Fisheries Science
}

\author{
Benjamin S. Freeling and Sean D. Connell* \\ Southern Seas Ecology Laboratories, School of Biological Sciences, The University of Adelaide, Adelaide, SA, Australia
}

Keywords: aquatic animals, fisheries science, pain, sentience, social trajectory

\section{INTRODUCTION}

Since its inception (Lee, 1912; Baranov, 1916; Beverton and Holt, 1957), fisheries science has tried to answer the question: "How can we maximize the benefits of fisheries for humanity?" Historically, those benefits have included yield and profit, as well as socially and ecologically sustainable systems (Olver et al., 1995; Mardle et al., 2002; Pascoe et al., 2017). So, fisheries science and management have always been driven by a set of values-that humanity should utilize marine resources to benefit itself (Partelow, 2018). What would happen if those values, which have formed the foundation of fisheries science and management for a century, were transformed by a new governance mind-set?

\section{OPEN ACCESS}

Edited by:

Nancy Louise Shackell, Bedford Institute of Oceanography (BIO), Canada

Reviewed by: Carla Forte Maiolino Molento, Federal University of Paraná, Brazil Liv Baker, Hunter College (CUNY), United States Simon Eckerström Liedholm, Wild Animal Initiative, United States

*Correspondence:

Sean D. Connell

sean.connel/@adelaide.edu.au

Specialty section:

This article was submitted to Marine Fisheries, Aquaculture and

Living Resources,

a section of the journal

Frontiers in Marine Science

Received: 24 March 2021

Accepted: 14 July 2021

Published: 05 August 2021

Citation:

Freeling BS and Connell SD (2021) Animal Minds, Social Change, and the

Future of Fisheries Science.

Front. Mar. Sci. 8:684841.

doi: 10.3389/fmars.2021.684841

\section{FISH SENTIENCE: PHILOSOPHICAL AND SCIENTIFIC DEBATES}

In mainstream society in modern, industrialized countries, it is broadly accepted that humans have morally relevant interests. The Universal Declaration of Human Rights "articulated the rights and freedoms to which every human being is equally and inalienably entitled" (United Nations., 2015). However, this broadly accepted view excludes non-human animals-a position that is challenged in science and philosophy. Philosopher Bentham (1789) argued that having morally relevant interests requires merely the capacity for enjoyment and suffering. Many contemporary philosophers agree that an organism's moral status should be determined by one criterion only: that organism's sentience (Singer, 2011a; Gruen, 2017). Here, we define "sentience" as the "capacity for emotion, pleasure and pain" (Boyle, 2009), while acknowledging that there is no widely accepted definition of sentience (Proctor et al., 2013).

When it comes to fish ${ }^{1}$, research, and academic debate on sentience has mostly focused on negative feelings, specifically pain (Proctor, 2012; Vettese et al., 2020). Researchers who support that fish feel pain begin with two key considerations: if fish can experience pain, fish should respond to noxious stimuli differently to innocuous stimuli (e.g., physiological reactions, protective responses), and fish should exhibit long-term behavioral (e.g., motivational) changes that imply higher-order processing (Braithwaite, 2010; Sneddon et al., 2014; Sneddon, 2020). Since the foundational studies on fish pain (Ehrensing et al., 1982; Chervova, 1997; Chervova and Lapshin, 2000; Sneddon et al., 2003a,b; Dunlop and Laming, 2005; Dunlop et al., 2006; Nordgreen et al., 2007), the body of evidence has developed such that the two key considerations are now considered well-supported (Sneddon, 2015, 2020; reviewed in Brown, 2015; Elwood, 2021).

Conversely, some scientists remain skeptical of pain in fish. These skeptics mainly point to differences in brain structure between humans and fish and alleged methodological, conceptual, and logical flaws in empirical studies on fish pain (Rose et al., 2014; Key, 2016a; Browman et al., 2019). Skeptics also offer counter examples of studies, notably not designed to answer this question, where potentially noxious stimuli seemingly failed to cause behavioral changes (Rose et al., 2014; but see Arlinghaus et al., 2007; Brownscombe et al., 2017).

\footnotetext{
${ }^{1}$ We focus on fish as defined biologically. Most of our arguments readily extend to other exploited groups of animals (e.g., crustaceans, mammals), although the empirical evidence on sentience in those groups introduces further complexity.
} 
Many outside the debate have recognized that the evidence is not balanced; skeptics are reluctant to accept even a disproportionately large body of evidence, often seeking absolute proof (Proctor, 2012). Compared to other areas of science, which are comfortable with ambiguity, this attitude has been labeled a "double standard" (Griffin, 2001) and a taboo that restricts progress (Griffin, 2013).

Empirical research on sentience, combined with a philosophical emphasis on sentience rather than species, leads many people to question the separation of Homo sapiens and other species of sentient animals (Donaldson and Kymlicka, 2011). One solution offered is to adapt society's institutions to recognize and protect the interests ${ }^{2}$ of sentient animals, and political theory illustrates how such a change could be made (Stone, 2010; Donaldson and Kymlicka, 2011; Andrews et al., 2018; Vink, 2020; Freeling and Connell, 2021).

Regardless of method, the legal protection of animals would change the fabric of society. Modern social, industrial, and economic systems assume that the use of animals is permissible, whether for food, fabrics, land management, or medical testing. Where society has historically undergone profound economic transformations, humans' everyday lives have been altered in significant ways; the abolition of state-sanctioned slavery is one example (Goldin, 1973; Katz-Hyman, 2008). For these reasons, Browman et al. (2019) wisely express caution about granting legal protection to animals purely on the basis of unclear science. However, this major societal conversation involves many factors outside an objective reading of empirical data.

Browman et al. (2019) assume that humans and fish are fundamentally different, and that any potential similarities are merely tentative until conclusively proven. To accept that fish feel pain departs from the status quo of society, so the burden of proof lies with those who believe fish feel pain (Key, 2016b). However, other authors begin at a different perspective: that humans and fish are fundamentally similar, and that it is the potential differences that are merely tentative until conclusively proven (Safina, 2016).

\section{WHAT DETERMINES SOCIETY'S DECISION?}

The conclusion that a scientist draws from a piece of evidence may sometimes depend more on the paradigm within which initial assumptions are made than the evidence itself (Kuhn, 1996; Nuzzo, 2015; Andersen et al., 2019; but see Nickles, 2017). Cognitive biases encourage people to selectively focus on evidence that supports their existing beliefs (Tetlock, 2003; Kahneman, 2012). Beyond the scientific debate, the two divergent assumptions in the scientific literature serve different groups in broader society (Vettese et al., 2020).

\footnotetext{
${ }^{2}$ For clarity, when discussing the moral status of sentient organisms, we refer to "interests," which we believe is an appropriate way to envision the aggregative, potentially conflicting needs of all sentient organisms (Gruen, 2017). When discussing legal and political form that aims to protect those interests, we speak of "legal rights".
}

The two divergent assumptions about where the burden of proof lies may be explained using the moral circle. Humans use the moral circle to separate beings into two groups: those who have morally relevant interests, and those who do not (Laham, 2009; Singer, 2011b). In this way, a person whose moral circle includes fish may place the burden on scientists to prove that fish are not sentient; as such, they may conclude that the evidence supports fish sentience. Conversely, a person whose moral circle does not include fish may place the burden on people who support that fish are sentient, and accordingly conclude that the evidence does not yet support fish sentience. In other words, the conclusion that a person draws may be primarily determined by their pre-existing beliefs-for scientists (Koehler, 1993) as well as members of the public (Kahan, 2012) but see Tappin et al. (2020). Of course, an alternative interpretation is that a person's moral circle may be determined by their reading of the evidence on sentience in different animals, or a complex interaction between the evidence and their pre-existing beliefs (Helton and Helton, 2005). However, prejudices against animals appear to stem from the same origin as prejudices against other humans, suggesting at least some resistance to evidence (Dhont and Hodson, 2014; Dhont et al., 2016).

Even under uncertainty, progress may arise from the expected utility principle; fish could be assigned a moral value that incorporates the probability that they are sentient, a probability that can be obtained through deliberation between all parties (Sebo, 2015). Such a probability could be incorporated in a welfare function (below). This represents a rational middleground between the risky in cautionary principle (assuming nonsentience) and the pre-cautionary principle (assuming sentience) (Birch, 2017; Sebo, 2018).

Regardless, the continued existence of two polar-opposite readings of the same set of evidence suggests that, unless a transformational piece of research arises that conclusively settles the debate, these two divergent positions are likely to co-exist for the foreseeable future. What implications might this continued co-existence hold for the societal conversation?

If our explanation is true, then the primary determinant of whether a society legally protects animals' interests may not be the direction of the empirical evidence, but whether that society's moral circle is expanding or contracting (Arlinghaus et al., 2007). Humanity's moral circle has appeared to have broadened throughout modern history, and developed countries in the twenty-first century have achieved a level of egalitarianism among humans that would have seemed impossible just a few centuries ago (Pinker, 2012), although some potential exceptions have been identified (Branwen, 2019). Also, we emphasize that moral circle expansion depends on many complex, interrelated factors, including scientific evidence but also economic progress, technology, social contexts, psychological prejudices, and historical path-dependence (Pinker, 2018; Anthis and Paez, 2021), all of which influence the pathway from science to moral circle expansion and policy change.

Nevertheless, there does appear to be a historical trajectory toward greater compassion for terrestrial and aquatic animals by the general public (Reese, 2018; Freeling and Connell, 2020; Anthis and Paez, 2021). Recently, multiple research groups have 
emerged with stated aims to reduce suffering in fish and other wild animals (Billington, 2019; Wild Animal Initiative, 2019; Bench et al., 2020). Public opinion surveys often estimate that a majority of respondents believe fish to be sentient and capable of experiencing emotions, as shown in the European Union (ComRes., 2018) and South America (Rucinque et al., 2017), although results are sometimes mixed (Kupsala et al., 2013; Šimčikas, 2020).

If public support for the protection of fish continues to grow, then the societal conversation on the legal protection of aquatic animals may become urgent. While mainstream discourse centers on more humane methods of catching fish (e.g., Veldhuizen, 2018), the legal protections we envision here are more profound. An emerging body of thought is investigating how sentient organisms can be enfranchised and represented in political institutions and recognized as bearers of legal rights and freedoms-simply put, a generalization of human rights to sentient rights (Donaldson and Kymlicka, 2011; Cochrane, 2018; Vink, 2020; Freeling and Connell, 2021; Paez, 2021). As with the economic sacrifices involved with abolishing slavery (Conrad and Meyer, 1958), the path of granting constitutional protection to fish may necessitate serious sacrifices in wealth, employment, and food security (Browman et al., 2019). Conversely, fish production does involve complex relationships with social and environmental problems (e.g. Lima dos Santos and Howgate, 2011; Reis et al., 2021), so granting protection to fish may actually help overcome problems in food security and public health.

While the dialogue between science and society can help overcome many challenges (Sonnino et al., 2021), social change may be determined by forces outside of the control of any individuals, even scientists (Arlinghaus et al., 2007; Pinker, 2018). A more tractable frontier is, if society does undergo a major shift in its relationship with aquatic ecosystems, whether fisheries scientists and managers will be prepared to support society in meeting society's chosen objectives. If society adopts the mindset that fish should be afforded legal protection to a degree comparable to humans, fisheries science may need to evolve once more.

\section{DISCUSSION}

Today, as fish populations are generally managed for the sake of human welfare [e.g., via economic growth (Ortiz-Ospina and Roser, 2013; Pascoe et al., 2017)], the fishery manager might aim to select a fishing effort that corresponds to the maximum profit:

$$
\max _{E} P R O F I T=R E V-C O S T
$$

Likewise, for a future fish population that is managed to optimize the total welfare of sentient organisms, the manager could aim to maximize an inclusive welfare function:

$$
\max _{E} W E L F A R E=?
$$

Here, we adopt the view of welfare that emphasizes the subjective experiences of sentient animals (discussed in Browning, 2020). This welfare would include not only fish that constitute the population, but also all other sentient beings connected with the ecosystem, including humans. The state of an ecosystem that maximizes the welfare of sentient beings, if they are indeed capable of experiencing emotion, is a question ripe for study. Also, note that the above welfare function is a consequentialist mechanism; in contrast, deontological (rule-based) approaches may advocate for different actions in how fish are considered.

Generally, fisheries are managed to meet objectives under three categories: economic, social, and environmental sustainability (Pascoe et al., 2017). Discourse on "natural resource management," and indeed viewing other organisms as a resource, remains anthropocentric (Treves et al., 2019) and potentially speciesist (Horta, 2010). From this perspective, efforts to improve fish welfare (e.g. Moore et al., 2009; Kennelly and Broadhurst, 2021) are generally secondary to the primary goal of exploiting the fishery for food or profit.

However, under a sentient-inclusive welfare function, maximizing the total welfare of sentient beings would be the core objective-even at the expense of humanity's exploitation of non-human organisms. As such, catching a large-bodied shark to sustain many members of an artisanal fishing community could be a welfare-maximizing strategy, while catching many small-bodied fish to produce replaceable goods for developed countries may not (Gruen, 2017). Note that some researchers propose that wild animals experience lives not worth living; while this does not conflict with improving animal welfare, it may introduce complexities in doing so (Fischer, 2018).

A handful of researchers have begun to identify what conditions might maximize the welfare of fish at the population level. One stream of research considers physiology and behavior, often studying fish in laboratories or the field. This approach aims to determine which indicators could shed light on the inner state of fish minds, and considers how observations of the animals (e.g. respiration rates) correspond to observations of their environment (e.g. dissolved oxygen) (Martins et al., 2012; Beausoleil et al., 2018; Noble et al., 2018; Cerqueira and Billington, 2020). A key motivation is to improve conditions for fish in aquaculture or fisheries.

A second, theoretical stream of research adopts quantitative modeling. One question is whether fish welfare can be measured quantitatively, and how researchers could approach doing so (Singer, 2011a; Hecht, 2019a; e.g., Bateson, 2016; Brennan, 2018; Teng et al., 2018). Beyond this key question, preliminary forays have suggested that individual fish welfare within a population may be maximized at a specific population density (Hecht, 2019b), and that the total welfare in a population could be influenced by the age-structure (Hecht, 2019a). These intriguingly counter-intuitive ideas clarify that the optimal fishing effort, in terms of total welfare of sentient organisms, may be non-zero and could also involve complex relationships with population dynamics. Furthermore, beyond the relief from suffering, sentient organisms have an interest in remaining alive (Dogăn, 2011); the management of wild populations for the benefit of all sentient organisms would also need to consider this interest in life.

These quantitative, empirical questions are ripe for investigation by fisheries science. The two streams of research 
can also feed into decision-making. Policymakers could apply empirical findings to update existing tools in welfare economics to account for non-humans (Johansson-Stenman, 2018). This would enable policymakers to achieve a mandate of promoting the interests of all sentient organisms, should society choose to prioritize those interests.

Since the publication of the seminal texts that founded modern fisheries science (e.g., Lee, 1912; Baranov, 1916; Beverton and Holt, 1957), society has experienced immense transformation. In deciding whether the rights of fish should be protected by law, society faces a choice. This choice may primarily consider existing worldviews rather than any scientific consensus. If society pursues the path of legally enshrining the interests of sentient organisms, fisheries science can support society in doing so. The question of how fish populations can be managed to explicitly protect their interests represent this exciting frontier for fisheries science.

\section{REFERENCES}

Andersen, F., Anjum, R. L., and Rocca, E. (2019). Philosophical bias is the one bias that science cannot avoid. eLife 8:e44929. doi: 10.7554/eLife.44929

Andrews, K., Comstock, G. L., Crozier, G. K. D., Donaldson, S., Fenton, A., John, T. M., et al. (2018). Chimpanzee Rights: The Philosophers' Brief. London: Routledge.

Anthis, J. R., and Paez, E. (2021). Moral circle expansion: a promising strategy to impact the far future. Futures 130:102756. doi: 10.1016/j.futures.2021.102756

Arlinghaus, R., Cooke, S. J., Lyman, J., Policansky, D., Schwab, A., Suski, C., et al. (2007). Understanding the complexity of catch-and-release in recreational fishing: an integrative synthesis of global knowledge from historical, ethical, social, and biological perspectives. Rev. Fish Sci. 15, 75-167. doi: 10.1080/10641260601149432

Baranov, F. (1916). On the Question of the Biological Foundations of Fisheries. Moscoe: Mosc Febr.

Bateson, M. (2016). Cumulative stress in research animals: telomere attrition as a biomarker in a welfare context? BioEssays 38: 201-212. doi: 10.1002/bies.201500127

Beausoleil, N. J., Mellor, D. J., Baker, L., Baker, S. E., Bellio, M., Clarke, A. S., et al. (2018). "Feelings and fitness" not "feelings or fitness"-the raison d'être of conservation welfare, which aligns conservation and animal welfare objectives. Front. Vet. Sci. 5:296. doi: 10.3389/fvets.2018.00296

Bench, W., Billington, T., King-Nobles, H., and Schwartz, R. (2020). New EA Fish Orgs: Collaboration between Fish Welfare Initiative and Aquatic Life Institute. Eff Altruism Forum.

Bentham, J. (1789). An Introduction to the Principles of Morals and Legislation. London: T. Payne.

Beverton, R., and Holt, S. (1957). On the Dynamics of Exploited Fish Populations. London: H.M. Stationery Off.

Billington, T. (2019). Introducing Fish Welfare Initiative. Effective Altruism Forum. Available online at: https://forum.effectivealtruism.org/posts/ iMofrSc86iSR7EiAG/introducing-fish-welfare-initiative-1 (accessed March 8, 2021).

Birch, J. (2017). Animal sentience and the precautionary principle. Anim. Sent. 2:1200. doi: $10.51291 / 2377-7478.1200$

Boyle, E. (2009). Neuroscience and animal sentience. Neuroscience 112. Available online at: https://citeseerx.ist.psu.edu/viewdoc/download?doi=10.1.1. 573.1658\&rep=rep1\&type=pdf (accessed March 17, 2021).

Braithwaite, V. (2010). Do Fish Feel Pain? New York, NY: Oxford University Press.

Branwen, G. (2019). The Narrowing Circle. Gwern.net. Available online at: https:// www.gwern.net/The-Narrowing-Circle (accessed June 24, 2021).

\section{AUTHOR CONTRIBUTIONS}

BSF: conceptualization, investigation, writing-original draft, review and editing. SDC: writing-review and editing, supervision, and funding acquisition. Both authors contributed to the article and approved the submitted version.

\section{FUNDING}

BSF was supported by an Australian Government Research Training Program Scholarship. SDC was supported by the Australian Research Council (ARC LP200201000).

\section{ACKNOWLEDGMENTS}

We gratefully acknowledge the constructive advice of the three reviewers, as well as assistance from Sophie W. Calvin, all of which greatly improved the quality of the manuscript.

Brennan, O. (2018). "Fit and Happy": How do we measure wild-animal suffering? Wild-Anim. Suff. Res. 12, 225-228.

Browman, H. I., Cooke, S. J., Cowx, I. G., Derbyshire, S. W. G., Kasumyan, A., Key, B., et al. (2019). Welfare of aquatic animals: where things are, where they are going, and what it means for research, aquaculture, recreational angling, and commercial fishing. ICES J. Mar. Sci. 76, 82-92. doi: 10.1093/icesjms/fsy067

Brown, C. (2015). Fish intelligence, sentience and ethics. Anim. Cogn. 18:1-17. doi: 10.1007/s10071-014-0761-0

Browning, H. (2020). Assessing Measures of Animal Welfare. PhilArchive pre-print. Available online at: https://philarchive.org/rec/BROAMO-7?all_versions=1 (accessed June 26, 2021).

Brownscombe, J. W., Danylchuk, A. J., Chapman, J. M., Gutowsky, L. F. G., and Cooke, S. J. (2017). Best practices for catch-and-release recreational fisheries-angling tools and tactics. Fish Res. 186, 693-705. doi: 10.1016/j.fishres.2016.04.018

Cerqueira, M., and Billington, T. (2020). Fish Welfare Improvements in Aquaculture. London: Fish Welfare Initiative.

Chervova, L. S., and Lapshin, D. N. (2000). "Opioid modulation of pain threshold in fish," in Doklady Biological Sciences. Amsterdam: Kluwer Academic/Plenum Publishers.

Chervova, L. S. (1997). Pain sensitivity and behavior of fishes. J. Ichthyol. $37,98-102$.

Cochrane, A. (2018). Sentientist Politics: A Theory of Global Inter-Species Justice. New York, NY: Oxford University Press.

ComRes. (2018). Eurogroup for Animals/CIWF Fish Welfare Survey. Poland: Czech Republic.

Conrad, A. H., and Meyer, J. R. (1958). The economics of slavery in the ante bellum South. J. Polit. Econ. 66, 95-130. doi: 10.1086/258020

Dhont, K., and Hodson, G. (2014). Why do right-wing adherents engage in more animal exploitation and meat consumption? Personal Individ. Differ. 64, 12-17. doi: $10.1016 /$ j.paid.2014.02.002

Dhont, K., Hodson, G., and Leite, A. C. (2016). Common ideological roots of speciesism and generalized ethnic prejudice: the social dominance human-animal relations model (SD-HARM). Eur. J. Personal 30, 507-522. doi: 10.1002/per.2069

Dogăn, A. (2011). A defense of animal rights. J. Agric. Environ. Ethics 24, 473-491. doi: 10.1007/s10806-010-9273-3

Donaldson, S., and Kymlicka, K. (2011). Zoopolis: A Political Theory of Animal Rights. Oxford: Oxford University Press.

Dunlop, R., and Laming, P. (2005). Mechanoreceptive and nociceptive responses in the central nervous system of goldfish (Carassius auratus) and trout (Oncorhynchus mykiss). J. Pain 6, 561-568. doi: 10.1016/j.jpain.2005.02.010 
Dunlop, R., Millsopp, S., and Laming, P. (2006). Avoidance learning in goldfish (Carassius auratus) and trout (Oncorhynchus mykiss) and implications for pain perception. Appl. Anim. Behav. Sci. 97, 255-271. doi: $10.1016 /$ j.applanim.2005.06.018

Ehrensing, R. H., Michell, G. F., and Kastin, A. J. (1982). Similar antagonism of morphine analgesia by MIF-1 and naloxone in Carassius auratus. Pharmaco. Biochem. Behav. 17, 757-761. doi: 10.1016/0091-3057(82)90358-6

Elwood, R. W. (2021). potential pain in fish and decapods: similar experimental approaches and similar results. Front. Vet. Sci. 8: 8. doi: $10.3389 /$ fvets.2021.631151

Fischer, B. (2018). Individuals in the wild. Anim. Sentience 3. doi: $10.51291 / 2377-7478.1382$

Freeling, B. S., and Connell, S. D. (2020). Funding conservation through an emerging social movement. Trends Ecol. Evol. 35, 3-6. doi: 10.1016/j.tree.2019.09.002

Freeling, B. S., and Connell, S. D. (2021). Advancing government legitimacy through the scientific study of sentience. World Futur. in press. 1-10. doi: 10.1080/02604027.2021.1944732

Goldin, C. D. (1973). The economics of emancipation. J. Econ. Hist. 33, 66-85. doi: $10.1017 /$ S0022050700076440

Griffin, D. R. (2001). Animals know more than we used to think. Proc. Natl. Acad. Sci. 98, 4833-4834. doi: 10.1073/pnas.091088198

Griffin, D. R. (2013). Animal Minds: Beyond Cognition to Consciousness. Chicago, IL: University of Chicago Press.

Gruen, L. (2017). The Moral Status of Animals. Stanford, CA: Stanf Encycl Philos Arch.

Hecht, L. (2019a). Accounting for demography in the assessment of wild animal welfare. bioRxiv 819565. doi: 10.1101/819565

Hecht, L. (2019b). Optimal population density: trading off the quality and quantity of welfare. Wild Anim Initiat. 224.

Helton, W. S., and Helton, N. D. (2005). Changing animal and environmental attitudes with evidence of animal minds. Appl. Environ. Educ. Commun. 4, 317-323. doi: 10.1080/15330150500302114

Horta, O. (2010). What is speciesism? J. Agric. Environ. Ethics 23, 243-266. doi: 10.1007/s10806-009-9205-2

Johansson-Stenman, O. (2018). Animal welfare and social decisions: is it time to take Bentham seriously? Ecol. Econ. 145, 90-103. doi: 10.1016/j.ecolecon.2017.08.019

Kahan, D. M., (2012). Ideology, motivated reasoning, and cognitive reflection: an experimental study. Judgm. Decis. Mak. 8, 407-424. doi: 10.2139/ssrn.2182588

Kahneman, D. (2012). Thinking, Fast and Slow. London: Penguin Press.

Katz-Hyman, M. (2008). doing good while doing well: the decision to manufacture products that supported the abolition of the slave trade and slavery in Great Britain. Slavery Abolit. 29, 219-231. doi: 10.1080/01440390802027871

Kennelly, S. J., and Broadhurst, M. K. (2021). A review of bycatch reduction in demersal fish trawls. Rev. Fish Biol. Fish 31, 289-318. doi: $10.1007 /$ s11160-021-09644-0

Key, B. (2016a). Why fish do not feel pain. Anim. Sentience 1:1. doi: $10.51291 / 2377-7478.1011$

Key, B. (2016b). Burden of proof lies with proposer of celestial teapot hypothesis. Anim. Sentience 1:1094. doi: 10.51291/2377-7478.1094

Koehler, J. J. (1993). The influence of prior beliefs on scientific judgments of evidence quality. Organ Behav. Hum. Decis. Process 56, 28-55. doi: 10.1006/obhd.1993.1044

Kuhn, T. S. (1996). The Structure of Scientific Revolutions 3e. Chicago, IL: University of Chicago Press.

Kupsala, S., Jokinen, P., and Vinnari, M. (2013). Who cares about farmed fish? citizen perceptions of the welfare and the mental abilities of fish. J. Agric. Environ. Ethics 26, 119-135. doi: 10.1007/s10806-0119369-4

Laham, S. M. (2009). Expanding the moral circle: Inclusion and exclusion mindsets and the circle of moral regard. J. Exp. Soc. Psychol. 45, 250-253. doi: $10.1016 /$ j.jesp.2008.08.012

Lee, R. M. (1912). An investigation into the methods of growth determination in fishes. Publ. Circonst. Cons. Int. Explor. Mer. 63, 1-35.

Lima dos Santos, C. A. M., and Howgate, P. (2011). Fishborne zoonotic parasites and aquaculture: a review. Aquaculture 318, 253-261. doi: 10.1016/j.aquaculture.2011.05.046
Mardle, S., Pascoe, S., Boncoeur, J., Gallic, B. L., García-Hoyo, J. J., Herrero, I., et al. (2002). Objectives of fisheries management: case studies from the UK, France, Spain and Denmark. Mar. Policy 26, 415-428. doi: 10.1016/S0308-597X(02)00022-2

Martins, C. I., Galhardo, L., Noble, C., Damsgård, B., Spedicato, M. T., Zupa, W., et al. (2012). Behavioural indicators of welfare in farmed fish. Fish. Physiol. Biochem. 38, 17-41. doi: 10.1007/s10695-011-9518-8

Moore, J. E., Wallace, B. P., Lewison, R. L., Žydelis, R., Cox, T. M., and Crowder, L. B. (2009). A review of marine mammal, sea turtle and seabird bycatch in USA fisheries and the role of policy in shaping management. Mar. Policy. 33, 435-451. doi: 10.1016/j.marpol.2008.09.003

Nickles, T. (2017). "Historicist theories of scientific Rationality," in The Stanford Encyclopedia of Philosophy, ed E. N. Zalta (Stanford, CA: Metaphysics Research Lab, Stanford University).

Noble, C., Gismervik, K., Iversen, M. H., Kolarevic, J., Nilsson, J., Stien, L. H., et al. (2018). Welfare Indicators for Farmed Atlantic Salmon-Tools for Assessing Fish Welfare. Tromso: Nofima.

Nordgreen, J., Horsberg, T. E., Ranheim, B., and Chen, A. C. (2007) Somatosensory evoked potentials in the telencephalon of Atlantic salmon (Salmo salar) following galvanic stimulation of the tail. J. Comp. Physiol. A 193, 1235-1242. doi: 10.1007/s00359-007-0283-1

Nuzzo, R. (2015). How scientists fool themselves-and how they can stop. Nature 526, 182-185. doi: 10.1038/526182a

Olver, C. H., Shuter, B. J., and Minns, C. K. (1995). Toward a definition of conservation principles for fisheries management. Can. J. Fish Aquat. Sci. 52, 1584-1594. doi: 10.1139/f95-751

Ortiz-Ospina, E., and Roser, M. (2013). Happiness and Life Satisfaction. Our World Data.

Paez, E. (2021). A republic for all sentients: Social freedom without free will. Pac. Philos. Q. In press. 1844-1915. doi: 10.1111/papq.12351

Partelow, S. (2018). A review of the social-ecological systems framework: applications, methods, modifications, and challenges. Ecol. Soc. 23:36. doi: 10.5751/ES-10594-230436

Pascoe, S. D., Plagányi, É. E., and Dichmont, C. M. (2017). Modelling multiple management objectives in fisheries: Australian experiences. ICES J. Mar. Sci. 74, 464-474. doi: 10.1093/icesjms/fsw051

Pinker, S. (2012). The Better Angels of Our Nature: Why Violence Has Declined. New York, NY: Penguin Publishing Group.

Pinker, S. (2018). Enlightenment Now: The Case for Reason, Science, Humanism, and Progress. New York, NY: Viking.

Proctor, H. (2012). Animal sentience: Where are we and where are we heading? Anim. Open Access J. MDPI 2, 628-639. doi: 10.3390/ani2040628

Proctor, H., Carder, G., and Cornish, A. R. (2013). Searching for animal sentience: a systematic review of the scientific literature. Anim. Open Access. J. MDPI 3, 882-906. doi: 10.3390/ani3030882

Reese, J. (2018). The End of Animal Farming. Boston: Beacon Press.

Reis, G. G., Heidemann, M. S., Goes, H. A. A., and Molento, C. F. M. (2021). Can radical innovation mitigate environmental and animal welfare misconduct in global value chains? The case of cell-based tuna. Technol. Forecast Soc. Change 169:120845. doi: 10.1016/j.techfore.2021.120845

Rose, J. D., Arlinghaus, R., Cooke, S. J., Diggles, B. K., Sawynok, W., Stevens, E. D., et al. (2014). Can fish really feel pain? Fish. Fish. 15, 97-133. doi: 10.1111/faf.12010

Rucinque, D. S., Souza, A. P. O., and Molento, C. F. M. (2017). Perception of fish sentience, welfare and humane slaughter by highly educated citizens of Bogotá, Colombia and Curitiba, Brazil. PLOS ONE 12:e0168197. doi: 10.1371/journal.pone. 0168197

Safina, C. (2016). Fish pain's burden of proof. Anim. Sentience 3:45. doi: $10.51291 / 2377-7478.1095$

Sebo, J. (2015). Reconsider the Lobster. What's Wrong?. Available online at: https:// whatswrongcvsp.com/2015/09/09/reconsider-the-lobster/ (accessed June 18, 2021).

Sebo, J. (2018). The moral problem of other minds. Harv. Rev. Philos. 25, 51-70. doi: 10.5840/harvardreview20185913

Šimčikas, S. (2020). How Much Do Europeans Care About Fish Welfare?. Rethink Priorities. Available online at: https://www.rethinkpriorities.org/blog/2020/ 6/22/how-much-do-europeans-care-about-fish-welfare (accessed March 10, 2021). 
Singer, P. (2011a). Practical Ethics. New York, NY: Cambridge University Press.

Singer, P. (2011b). The Expanding Circle: Ethics, Evolution, and Moral Progress. Princeton, NJ: Princeton University Press.

Sneddon, L. U. (2015). Pain in aquatic animals. J. Exp. Biol. 218, 967-976. doi: $10.1242 /$ jeb.088823

Sneddon, L. U. (2020). “Can Fish Experience Pain?” in The Welfare of Fish, eds T. S. Kristiansen, A. Fernö, M. A, Pavlidis, H. van de Vis (New York, NY: Springer International Publishing).

Sneddon, L. U., Braithwaite, V. A., and Gentle, M. J. (2003a). Do fishes have nociceptors? Evidence for the evolution of a vertebrate sensory system. Proc. R. Soc. B Biol. Sci. 270, 1115-1121. doi: 10.1098/rspb.2003.2349

Sneddon, L. U., Braithwaite, V. A., and Gentle, M. J. (2003b). Novel object test: examining nociception and fear in the rainbow trout. J. Pain 4, 431-440. doi: 10.1067/S1526-5900(03)00717-X

Sneddon, L. U., Elwood, R. W., Adamo, S. A., and Leach, M. C. (2014). Defining and assessing animal pain. Anim. Behav. 97, 201-212. doi: 10.1016/j.anbehav.2014.09.007

Sonnino, A., Carrabba, P., Curatella, M., di Renzo, E., Fumagalli, L., Iannetta, M., et al. (2021). "(Re) thinking sciencesociety dialogue: the case of food and agriculture system," in Transdisciplinary Case Studies on Design for Food and Sustainability. (Amsterdam: Elsevier).

Stone, C. D. (2010). Should Trees Have Standing? Law, Morality, and the Environment. New York, NY: Oxford University Press.

Tappin, B. M., Pennycook, G., and Rand, D. G. (2020). Thinking clearly about causal inferences of politically motivated reasoning: why paradigmatic study designs often undermine causal inference. Curr. Opin. Behav. Sci. 34, 81-87. doi: 10.1016/j.cobeha.2020.01.003

Teng, K. T.-Y., Devleesschauwer, B., Noordhout, C. M. D., Bennett, P., McGreevy, P. D., Chiu, P.-Y., et al. (2018). Welfare-Adjusted Life Years (WALY): a novel metric of animal welfare that combines the impacts of impaired welfare and abbreviated lifespan. PLOS ONE 13:e0202580. doi: 10.1371 /journal.pone. 0202580
Tetlock, P. E. (2003). Thinking the unthinkable: sacred values and taboo cognitions. Trends Cogn. Sci. 7, 320-324. doi: 10.1016/S1364-6613(03)00135-9

Treves, A., Santiago-Ávila, F., and Lynn, W. (2019). Just preservation. Anim. Sentience 4:27. doi: 10.51291/2377-7478.1505

United Nations. (2015). Universal Declaration of Human Rights.

Veldhuizen, L. J. L., Berentsen, P. B. M., de Boer, I. J. M., van de Vis, J. W., Bokkers, E. A. M. (2018). Fish welfare in capture fisheries: a review of injuries and mortality. Fish Res. 204, 41-48. doi: 10.1016/j.fishres.2018. 02.001

Vettese, T., Franks, B., and Jacquet, J. (2020). The great fish pain debate. Issues Sci. Technol. 36, 49-53.

Vink, J. (2020). The Open Society and Its Animals. London: Palgrave Macmillan.

Wild Animal Initiative (2019). Announcing Wild Animal Initiative. Farmington MN: Wild Anim Initiat.

Conflict of Interest: The authors declare that the research was conducted in the absence of any commercial or financial relationships that could be construed as a potential conflict of interest.

Publisher's Note: All claims expressed in this article are solely those of the authors and do not necessarily represent those of their affiliated organizations, or those of the publisher, the editors and the reviewers. Any product that may be evaluated in this article, or claim that may be made by its manufacturer, is not guaranteed or endorsed by the publisher.

Copyright $\odot 2021$ Freeling and Connell. This is an open-access article distributed under the terms of the Creative Commons Attribution License (CC BY). The use, distribution or reproduction in other forums is permitted, provided the original author(s) and the copyright owner(s) are credited and that the original publication in this journal is cited, in accordance with accepted academic practice. No use, distribution or reproduction is permitted which does not comply with these terms. 